\title{
Regulation of Apoptosis by the Unfolded Protein Response
}

\author{
Andrew Fribley, Kezhong Zhang, and Randal J. Kaufman
}

\section{Summary}

In eukaryotic cells, the endoplasmic reticulum (ER) serves many specialized functions including biosynthesis and assembly of membrane and secretory proteins, calcium storage and production of lipids and sterols. As a plant for protein folding and posttranslational modification, the ER provides stringent quality control systems to ensure that only correctly folded proteins exit the ER and unfolded or misfolded proteins are retained and ultimately degraded. Biochemical, physiological, and pathological stimuli that interfere with ER function can disrupt ER homeostasis, impose stress to the ER, and subsequently cause accumulation of unfolded or misfolded proteins in the ER lumen. To deal with accumulation of unfolded or misfolded proteins, the cell has evolved highly specific signaling pathways collectively called the "unfolded protein response" (UPR) to restore normal ER functions. However, if the overload of unfolded or misfolded proteins in the ER is not resolved, the prolonged UPR will induce ER stress-associated programmed cell death, apoptosis, to protect the organism by removing the stressed cells. In this chapter, we summarize our current understanding of UPR-induced apoptosis and various methods to detect ER stress and apoptosis in mammalian cells.

\section{Keywords}

Apoptosis; Endoplasmic Reticulum Stress; Unfolded Protein Response

\section{Introduction}

\subsection{The Unfolded Protein Response}

As a unique protein-folding compartment and a dynamic calcium store, the ER is very sensitive to alterations in intracellular homeostasis. Perturbations that alter ER homeostasis disrupt folding and lead to the accumulation of unfolded proteins and protein aggregates which are detrimental to cell survival. Disturbances in intraluminal calcium or celluar redox status, increased demand for protein folding due to elevated synthesis of secretory proteins, the expression of mutant or misfolded proteins, nutrient/glucose deprivation or viral infection can all lead to stress in the ER. The ER has evolved highly specific signaling pathways collectively referred to as the unfolded protein response (UPR) that alter intracellular transcriptional and translational programs to deal with the accumulation of unfolded or misfolded proteins. Following the introduction of stress these pathways prevent continued accumulation of unfolded protein in the ER lumen by transiently attenuating general protein synthesis, increasing the lumenal folding capacity and the degradation of misfolded proteins through ER-associated protein degradation (ERAD) or autophagy (1-3).

The complex network of the UPR to ER stress is mediated by only a few ER transmembrane proteins: PERK (PKR-like ER kinase), IRE1 (inositol-requiring enzyme 1), and ATF6 (activating transcription factor 6) (3, 4). All these stress sensors have an ER lumenal domain that can sense the presence of unfolded or misfolded proteins, an ER transmembrane domain 
that targets the protein to the ER, and a functional cytosolic domain. Under resting conditions, all the three ER stress sensors are maintained in an inactive state through their association with the chaperone GRP78/BiP. When cells encounter ER stress, GRP78/BiP dissociates from the stress sensors and binds to underglycosylated, misfolded, or unassembled proteins, thus leading to activation of the UPR (Fig. 1).

1.1.1. PERK/elF2 $\alpha /$ CHOP Signaling and Apoptosis-The most immediate response to the accumulation of unfolded or misfolded proteins is the activation of the ER transmembrane kinase PERK. Activated PERK phosphorylates the alpha subunit of eukaryotic translation initiation factor 2 (eIF2a) and attenuates general protein synthesis to reduce the lumenal client load in the stressed cells. Murine cells deleted in PERK or mutated at Ser51 in eIF2a to prevent phosphorylation did not attenuate protein synthesis upon ER stress and were significantly less able to survive stressful stimuli $(5,6)$. PERK activation promotes cell survival by limiting the protein-folding load on the ER and by inducing the transcription of specific UPR survival genes downstream of eIF2a (7). However, under prolonged or severe ER stress PERK-mediated activation of the transcription factor ATF4 has been demonstrated to induce CHOP/GADD153 (7) and also the proapoptotic BH3-only BCL2 family members NOXA and BIM (8). CHOP (C/EBP homologous protein) is a bZIPcontaining transcription factor that was identified as a member of the CCAAT/enhancer binding protein (C/EBP) family (9). Overexpression of CHOP induces cell cycle arrest or apoptosis by regulating expression of multiple genes encoding proapoptotic factors including DR5 (death receptor 5), TRB3 (Tribbles homolog 3), CAVI (carbonic anhydrase VI) (10-14); and CHOP-deficient cells are protected from ER stress-induced apoptosis (15). CHOP also contributes to apoptosis through activating ERO1a, an ER oxidase that promotes hyperoxidization of the ER (16), and through dimerization with cAMP-responsive element binding protein (CREB) which can suppress the expression of the survival protein Bcl2 (11).

1.1.2. The IRE1 $\alpha$ Pathway-Upon activation of the UPR, IRE1 is activated through homodimerization and trans-autophosphorylation which can also lead to transcriptional activation of CHOP (17). The mammalian genome contains two homologs of yeast IREI designated as IREIa and IREI $\beta$. Whereas IRE1a is expressed in most cells and tissues, with high-level expression in the pancreas and placenta, IRE1 $\beta$ expression is prominent only in intestinal epithelial cells $(18,19)$. Activated IRE1a can function as an endoribonuclease to initiate removal of a 26-nucleotide intron from X-box binding protein 1 (XbpI) mRNA. Spliced $X b p 1$ mRNA encodes a protein with a novel carboxy-terminus that acts as a potent transcriptional activator and spliced XBP1 induces expression of genes encoding enzymes that facilitate protein folding, secretion, or degradation (20-23). In addition to promoting CHOP accumulation to induce apoptosis, under ER stress conditions, IRE1a can serve as a scaffold to recruit TNF receptor-associated factor 2 (TRAF2) and c-Jun-N-terminal inhibitory kinase (JIK) to the ER membrane $(24,25)$. TRAF2 activates the apoptosissignaling kinase 1 (ASK1), a mitogen-activated protein kinase kinase kinase (MAPKKK) (26). Activated ASK1 leads to activation of the JNK protein kinase and mitochondriadependent caspase activation $(26,27)$. JNK activation is known to influence the cell-death machinery through phosphorylation of BCL2 family proteins including BCL2 and BIM, which subsequently promote cell death programs (28); activated IRE1a can modulate apoptosis through interaction with BAX and $\operatorname{BAK}(29,30)$.

1.1.3. The ATF6 Pathway-ATF6 is a bZIP transcription factor of the CREB/ATF family. There are two forms of ATF6, ATF6a, and ATF6 $\beta$ (also known as CREB-RP). Upon UPR activation, ATF6 is transported to Golgi where it is cleaved by site-1 protease (S1P) and site-2 protease (S2P) to generate a 50-kDa cytosolic b-ZIP-containing fragment 
that migrates to the nucleus to activate transcription in coordination with the transcription factor NF-Y which is required for ATF6 docking to ER-associated binding elements present in the promoter regions of the UPR target genes. Although ATF6a facilitates adaptation to ER stress, and ATF6 null MEFs appear to be more sensitive to ER stress-induced cell death, it is dispensable for classical UPR signaling $(17,31)$.

\subsection{ER Stress-Induced Caspase Activation}

Recent evidence suggests that under ER stress, proapoptotic Bcl2 proteins, Bak and Bax, undergo conformational alteration in the ER membrane to permit $\mathrm{Ca}^{2+}$ efflux into the cytoplasm $(32,33)$. The increase in $\mathrm{Ca}^{2+}$ concentration in the cytoplasm activates the calcium-dependent cysteine protease $\mathrm{m}$-Calpain, which subsequently cleaves and activates the ER-resident procaspase-12 $(34,35)$. Activated caspase-12 cleaves and activates procaspase- 9 and consequently leads to activation of the caspase cascade. Calpain-deficient MEFs have reduced ER stress-induced caspase-12 activation and are resistant to ER stressassociated apoptosis (36). In addition to Calpain, caspase-7 translocates from the cytosol to the cytoplasmic side of the ER membrane under ER stress, and interacts with caspase-12, leading to its activation (35). Activated caspase-12 activates caspase-9, which, in turn, forms the apoptosome with released Cytochrome $c$ and Apaf-1 to activate the executioner caspase- 3 and apoptosis. Although initial studies found that caspase-12 deficient cells could

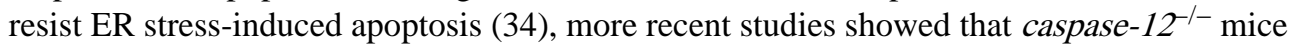
were not protected from cell death induced by ER stress (37). The requirement for caspase-12 for apoptosis in human cells is open to question, as the human caspase-12 gene contains several inactivating mutations (38). In addition, ER stress-induced $\mathrm{Ca}^{2+}$ release can also promote $\mathrm{Ca}^{2+}$ uptake into the mitochondrial matrix, leading to depolarization of mitochondrial inner membrane and Cytochrome $c$ release and formation of the apoptosome to activate caspase-3, DNA fragmentation, and cell death (39).

\section{Materials}

\subsection{Cell Culture, Stress-Inducing Compounds, and Lysis}

1. Dulbecco's Modified Eagle's Medium (DMEM) supplemented with Pen:Strep and $10 \%$ Fetal Bovine Serum (FBS) (Invitrogen).

2. Thapsigargin (Calbiochem) is dissolved at $500 \mu \mathrm{M}$ in DMSO.

3. Tunicamycin (Calbiochem) is dissolved at $10 \mathrm{mg} / \mathrm{mL}$ in DMSO.

4. Trizol (Invitrogen).

5. Modified Radioimmune-precipitation Assay (RIPA) buffer: $50 \mathrm{mM}$ sodium fluoride, $0.5-1.0 \% \mathrm{NP}-40,10 \mathrm{mM}$ sodium (mono) phosphate, $150 \mathrm{mM}$ sodium chloride, $25 \mathrm{mM}$ Tris (pH 8.0), $1 \mathrm{mM}$ phenylmethylsulfonylfluoride (PMSF), 2 $\mathrm{mM}$ ethylenediaminetetraacetic acid (EDTA), and $0.2 \mathrm{mM}$ sodium vanadate; prepared in $\mathrm{ddH}_{2} \mathrm{O}$. Immediately prior to use RIPA buffer is supplemented at 1:100 with $50 \mathrm{mM}$ PMSF and protease inhibitor cocktail (P3840 Sigma).

\subsection{Western Immunoblot Analysis and Immunoprecipitation of IRE1 $\alpha$ and PERK}

1. Protein Loading buffer (PLB), prepared by combining $3 \mathrm{~mL}$ of $20 \% \mathrm{SDS}, 3-\mathrm{mL}$ glycerol, $1.9 \mathrm{~mL}$ of $1 \mathrm{M}$ Tris (pH 6.8), $1.5 \mathrm{~mL}$ of 2-mercaptoethanol, $200 \mu \mathrm{g}$ bromophenol blue (15 mM final concentration), and $\mathrm{ddH}_{2} \mathrm{O}$ to $10.0 \mathrm{~mL}$.

2. PVDF membrane (\#162-0177 BioRad).

3. Tris-Buffered Saline with Tween (TBST) containing $145 \mathrm{mM} \mathrm{NaCl}, 10 \mathrm{mM}$ Tris (pH 8.0) and $0.1 \%$ Tween 20 prepared in $\mathrm{ddH}_{2} \mathrm{O}$. 
4. Nonfat powdered milk (Carnation).

5. Cell lysis buffer for immunoprecipitation-Western blot analysis is $1 \%$ NP- 40,50 $\mathrm{mM}$ Tris- $\mathrm{HCl}$ ( $\mathrm{pH} 7.5), 150 \mathrm{mM} \mathrm{NaCl}, 0.05 \%$ SDS, $0.5 \mathrm{mM}$ sodium vanadate, 100 $\mathrm{mM} \mathrm{NaF}, 50 \mathrm{mM}$ beta-glycerophosphate, and $1 \mathrm{mM}$ phenylmethylsulfonyl fluoride (PMSF) supplemented 1:100 with protease inhibitor cocktail (Sigma).

6. Protein A beads.

7. Primary antibodies: CREB2/ATF4 (sc-200, Santa Cruz), GADD153/CHOP (sc-793 or sc-575, Santa Cruz), eIF2a (\#9722, Cell Signaling), phospo-eIF2a (\#44-728G, Bio-source International), polyclonal rabbit anti-PERK-PITK-289 antibody was provided by Dr. Yuguang Shi (Lilly Research Laboratories) or from Cell Signaling (\#3179), GADD34 (sc-825 or sc-8327, Santa Cruz), GRP78/BiP (\#610978, BD Transduction Laboratories; or sc-1050, Santa Cruz), caspase3 (sc-7148, Santa Cruz), PARP (\#9542, Cell Signaling), NOXA (sc-22764, Santa Cruz), PUMA (\#4976, Cell Signaling), murine anti-human IRE1a primary antibody was raised in our lab.

8. Secondary horseradish peroxidase (HRP)-conjugated antibodies: Goat anti-mouse $\mathrm{IgG}(\mathrm{H}+\mathrm{L})(\mathrm{BioRad})$, and goat anti-rabbit $\mathrm{IgG}(\mathrm{H}+\mathrm{L})$ (Promega).

9. Super Signal West Pico Chemiluminescent Substrate reagent (Pierce).

10. Restore Western blot stripping buffer (Pierce).

\subsection{Reverse Transcription PCR, Conventional RT-PCR, and Quantitative PCR}

1. Multiscribe Reverse Transcriptase kit (Bio-Rad).

2. SYBR green PCR master mix (Bio-Rad).

3. Murine conventional reverse transcription PCR (RT-PCR):Xbp1 (total and spliced) forward $5^{\prime}$-CCTTGTGGTTG AGAACCAGG- $3^{\prime}$ and reverse $5^{\prime}$ -

CTAGAGGCTTGG TGTATAC- $3^{\prime}$ products for $X b p 1$ un-spliced and spliced are $451 \mathrm{bp}$ and $425 \mathrm{bp}$, respectively; GRP78/BiP forward 5' CTGGGTACATTTGATCTGACTGG-3' and reverse $5^{\prime}$ GCATCCTGGTGGCTTTCCAGCCATTC-3' product is $397 \mathrm{bp}$.

4. Murine quantitative real-time PCR (qPCR): Xbp1 (spliced) forward primer $5^{\prime}$ GAGTCCGCAGCAGGTG- $3^{\prime}$. This primer was designed to span the 26 base intron, thus can only anneal to the spliced $X b p 1$ transcript. The reverse primer sequence is $5^{\prime}$-GTGTCAGAGTCCATGGGA-3', which is 70 bases downstream of the forward primer. $X b p 1$ (spliced and un-spliced) forward primer $5^{\prime}$ -

AAGAACACGCTTGGGAA TGG-3 ${ }^{\prime}$, and reverse $5^{\prime}$ -

ACTCCCCTTGGCCTCCAC-3'; GRP78/BiP forward primer $5^{\prime}$ CATGGTTCTCACTAA AATGAAAGG-3' and reverse $5^{\prime}$ GCTGGTACAGTAACAA CTG-3'; Atf 4 forward 5' ATGGCCGGCTATGGATGAT- $3^{\prime}$ and reverse $5^{\prime}$ CGAAGTCAAACTCTTTCAGATCCATT-3'; Chop forward 5' CTGCCTTTCACCTTGGAGAC- $3^{\prime}$ and reverse $5^{\prime}$-CGT TTCCTGGGGATGAGATA- $3^{\prime} ; \beta$-actin forward primer $5^{\prime}$ GATCTGGCACCACACCTTCT- $3^{\prime}$, and reverse primer $5^{\prime}$ GGGGTGTTGAAGGTCTCAAA- ${ }^{\prime}$. We have found the use of GAPDH as an internal control for the induction of UPR-related mRNA transcripts to be less reliable than $\beta$-actin or 18 s ribosomal mRNA for reasons that are not entirely clear. 


\subsection{Nuclear DNA Fragmentation Assay}

1. DNA lysis buffer: $0.5 \mathrm{~mL}$ of $1 \mathrm{M}$ Tris-HCL (pH 7.4), $0.1 \mathrm{~mL}$ of $5 \mathrm{M} \mathrm{NaCl}, 1.0 \mathrm{~mL}$ of $0.5 \mathrm{M}$ EDTA (pH 8.0) and $2.5 \mathrm{~mL} 10 \%$ SDS; bring up to $50 \mathrm{~mL}$ with $\mathrm{ddH}_{2} 0$. Note: supplement with $100 \mu \mathrm{g} / \mathrm{mL}$ proteinase K immediately prior to use.

2. Phenol-chloroform (1:1).

3. $70 \%$ Ethanol.

4. RNAse A (Applied Biosystems).

\section{Methods}

Most studies examining mechanisms of ER stress-induced apoptosis are performed with the well-described pharmacological toxins tunicamycin or thapsigargin that cause severe ER stress. Tunicamycin interferes with N-linked glycosylation of polypeptides early in the secretory pathway, and thapsigargin is an effective inhibitor of $\mathrm{Ca}^{+2}$ ion pump proteins located in the membrane of the ER. Of the pathways implicated in ER stress-induced apoptosis, only the significance of the PERK/eIF2a pathway has been confirmed in several physiological models including pancreatic beta cell death in diabetes and macrophage cell death in atherosclerotic lesions $(6,40-42)$. Following tunicamycin or thapsigargin treatment the ER stress-inducible proapoptotic transcription factor CHOP plays a primary role in ER stress-induced death. Due to the fact that CHOP null murine embryonic fibroblasts are only partially protected from ER stress-induced apoptosis (15), it is likely that other stressinduced proapoptotic factors remain to be elucidated. Reliable methods have been established to characterize ER stress-induced apoptosis in vitro and in vivo. Here, we will discuss established experimental methods for the identification and characterization of ER stress-induced apoptosis mediated through PERK/eIF2a/CHOP signaling and by several BH3-only BCL2 family members.

\subsection{Cell Culture and Sample Preparation}

1. $1.5-2.0 \times 10^{5}$ murine embryonic fibroblasts (MEFs) are plated in $10-\mathrm{cm}$ tissue culture dishes $16-24 \mathrm{~h}$ prior to stress induction.

2. ER stress and apoptosis can be induced by treating cultures with $5.0-10.0 \mu \mathrm{g} / \mathrm{mL}$ tunicamycin (Tm) or 5.0-10.0 $\mu \mathrm{M}$ thapsigargin (Tg). To measure the induction of ER stress and effectively monitor the early and terminal stages of apoptosis, markers for the UPR and cell death should be observed over a range of time points. Whereas appreciable inductions of UPR markers such as eIF2a phosphorylation and CHOP and ATF4 occur within 4-6 h after the introduction of stressful stimuli, markers of apoptosis such as caspase activation and DNA fragmentation might not be observed until 8-24 h $(8,43)$.

3. To examine cultures for the induction of UPR markers samples should be harvested 1,4 , and $8 \mathrm{~h}$ following the addition of $\mathrm{Tm}$ or Tg. Care should be taken to note whether or not cells are attached to the tissue culture plates at the end of treatment. For attached cells, the medium is aspirated from the dishes and each is washed with $5 \mathrm{~mL}$ of ice-cold $1 \times$ PBS.

4. For mRNA analysis of UPR markers, $1 \mathrm{~mL}$ of Trizol (Invitrogen) should be added in a fume hood to each dish and mRNA can be harvested according to the manufacturer's protocol with the exception that an equal volume of isopropanol should be used to precipitate the mRNA.

5. For immunoblot analysis of UPR markers, $4 \mathrm{~mL}$ of fresh $1 \times \mathrm{PBS}$ is added and cells are scraped with a Teflon scraper or rubber policeman into the PBS and transferred 
to clearly labeled $15-\mathrm{mL}$ Falcon tubes. Cells are pelleted at $300-400 \times g$ in a swinging bucket centrifuge for 3-5 min, resuspended in 1-mL PBS, transferred into labeled 1.8-mL Eppendorf tubes and repelleted. The PBS is then aspirated from each pellet which is then resuspended in $30-60 \mu \mathrm{L}$ of modified RIPA buffer prepared as described ( see Subheading 2.1, step 5). The RIPA-suspended pellets are stored on ice for $20 \mathrm{~min}$. with periodic vortexing to mechanically dissociate cell membranes, and then spun at $4^{\circ} \mathrm{C}$ at $15,000-20,000 \times g$ for $15 \mathrm{~min}$. Cleared lysates (containing soluble cellular proteins) are then assayed with the Bradford assay to determine the concentration of protein in each whole-cell lysate. Lysates must be stored at $-80^{\circ} \mathrm{C}$.

6. To examine stress-induced cell cultures for markers of apoptosis (PARP, caspase3, NOXA, or PUMA) attached and floating cells are pooled, by scraping into the medium. The media containing the cells are then transferred into clearly labeled 15$\mathrm{mL}$ Falcon tubes and pelleted at 300-400 $\times g$ in a swinging bucket centrifuge for 3-5 min. Total mRNAs can be isolated for qPCR of NOXA, PUMA, or other BH3only BCL2 family members using Trizol or whole cell lysates can be prepared for Western immunoblot analysis of PARP and caspases in modified RIPA buffer as described (see Subheading 2.1, step 5).

\subsection{Western Immunoblot Analysis and Immunoprecipitation of IRE1 $\alpha$ and PERK 3.2.1. Western Immunoblot Analysis}

1. 25,50 , or $80 \mu \mathrm{g}$ of whole cell lysate is diluted in $3 \times$ PLB and denatured by boiling for 4 min and iced until cool.

2. Denatured proteins are separated by SDS-PAGE on 7.5 or $10 \%$ polyacrylamide gels and transferred to PVDF membrane.

3. Transferred membranes are washed in $\mathrm{ddH}_{2} 0$ briefly and blocked for $1 \mathrm{~h}$ at room temperature in 5\% nonfat powdered milk in TBST.

4. PVDF membranes can be cut to examine the relative levels of more than one protein if there is sufficient difference in the size of the proteins of interest. Membranes are incubated with primary antibodies diluted in fresh 5\% milk-TBST overnight at $4^{\circ} \mathrm{C}$ on a rocking platform.

5. Membranes are washed three times for $10 \mathrm{~min}$ in TBST to remove excess primary antibodies and secondary antibodies are added at 1:3,000 (Rabbit-HRP) or 1:7,500 (Mouse-HRP) for $1 \mathrm{~h}$ at room temperature on a rocking platform.

6. Membranes are washed three times for $10 \mathrm{~min}$ in TBST to remove unbound secondary antibodies and visualized by incubating with Super Signal chemiluminescent reagent for 3-5 min and exposed to autoradiographic film.

\subsubsection{Immunoprecipitation of IRE1a or PERK}

1. $1 \mu \mathrm{L}$ of IRE1a or PERK antibody is incubated with $20-\mu \mathrm{L}$ protein A beads in NP-40 lysis buffer for $1 \mathrm{~h}$ on an end-over-end rotator at room temperature.

2. The antibody-bound beads are washed by adding $500 \mu \mathrm{L}$ lysis buffer in a $1.5-\mathrm{mL}$ microcentrifuge tube by rotating them at $4^{\circ} \mathrm{C}$ for $10 \mathrm{~min}$, and then spun in a microcentrifuge for $30 \mathrm{~s}$ at $8,200 \times g$. The supernatant is aspirated and the beads are washed two more times in a similar manner, and then placed on ice. 
3. Equal amounts $(\mu \mathrm{g})$ of whole cell lysate samples prepared as described (see Subheading 3.1) are added into the tubes with washed antibody-bound beads and incubated for $3 \mathrm{~h}$ at room temperature or overnight at $4^{\circ} \mathrm{C}$ with constant rotation.

4. After incubation, the beads are washed three times with 1-mL NP-40 lysis buffer and once with $1 \mathrm{~mL}$ of $1 \times$ PBS.

5. The PBS is aspirated from the tube containing the beads and then $10 \mu \mathrm{L}$ of PLB is added to the tube which is then denatured at $95^{\circ} \mathrm{C}$ for $5 \mathrm{~min}$.

6. Denatured proteins are separated by SDS-PAGE on 7.5 or $10 \%$ polyacrylamide gels and transferred to PVDF membrane.

7. The blots are incubated with the same IRE1a or PERK primary antibody at a 1:1,000 dilution in TBST with 5\% (w/v) nonfat powdered milk overnight at $4{ }^{\circ} \mathrm{C}$.

8. Following incubation with primary antibodies membranes are washed, probed with secondary antibodies, and visualized (see Subheading 3.2.1). Murine IRE1a protein is detected as one major band migrating with a molecular mass of $\sim 120 \mathrm{kDa}$ and murine PERK protein is detected migrating with a molecular mass of $\sim 170$ $\mathrm{kDa}$. After Tm treatment, the size of IRE1a and PERK protein is slightly increased due to phosphorylation.

\subsection{Conventional Reverse Transcription PCR and Quantitative PCR}

Upon activation of the UPR, the ER membrane-resident primary UPR transducer IRE1a is activated and functions as an endoribonuclease to remove a 26 base intron from the human or murine X-box binding protein $1(X b p l)$ mRNA to encode a potent UPR trans-activator. Due to the difficulty of detecting endogenous IRE1a protein, quantitative analysis of spliced and total $X b p 1$ mRNA is the most convenient and reliable method to measure the activation of the IRE1a-mediated UPR pathway.

It has been well established that induction of GRP78/BiP is a marker of ER stress and a central regulator of the activation of the UPR transducers IRE1a, PERK, and ATF6. An increased level of GRP78/BiP protein expression is a good marker for UPR activation following prolonged stress treatment. The observable increase in protein accumulation usually occurs more slowly than the accumulation of mRNA transcripts due in part to the long half-life of GRP78/BiP protein. Due to the durability of "pre-stress" GRP78/BiP protein and the late increase of protein expression that can be detected in whole-cell lysates, immunoblot analysis for GRP78/BiP is not a very sensitive measure to detect low levels of ER stress and UPR activation. Hence, the induction of ER stress and activation of the UPR can often remain undiscovered without examination of both GRP78/BiP protein and mRNA. Accurate and sensitive methods have been developed for quantification of spliced and total $X b p 1$ and GRP78/BiP mRNA in mammalian cells or tissue by using conventional RT-PCR or qPCR.

1. Total RNA is isolated from cell cultures with Trizol reagent. Trizol can be used according to the manufacturer's protocol with the exception that mRNAs should be precipitated with a volume of isopropanol equal to the recovered aqueous phase; this will dramatically enhance the yield.

2. Synthesis of cDNA from murine total RNA is performed using iScript cDNA synthesis kit (Bio-Rad). The reaction mixture $(20 \mu \mathrm{L})$ contains 500 ng total RNA, 4 $\mu \mathrm{L}$ of $5 \times$ iScript reaction mix, and $1 \mu \mathrm{L}$ reverse transcriptase (RT).

3. The reverse transcription reaction is incubated at $25^{\circ} \mathrm{C}$ for $10 \mathrm{~min}$, followed by incubation at $48^{\circ} \mathrm{C}$ for $30 \mathrm{~min}$, and then RT is inactivated at $85^{\circ} \mathrm{C}$ for $5 \mathrm{~min}$. 
4. The reaction mixture is diluted tenfold by addition of $180 \mu \mathrm{L}$ of nuclease-free water. The diluted cDNA mix from the reverse transcription reaction is subjected to semi-quantitative reverse transcription PCR or quantitative real-time PCR to determine levels of specific mRNAs.

5. For conventional semi-quantitative RT-PCR for $X b p 1$ or $G R P / B i P, 10 \mu \mathrm{L}$ of diluted cDNA template $(25 \mathrm{ng})$ is mixed with $200 \mu \mathrm{M}$ of each dNTP, $300 \mathrm{nM}$ forward and reverse primers, $5 \mu \mathrm{L}$ of $10 \times \mathrm{PCR}$ reaction buffer with $15 \mathrm{mM} \mathrm{MgCl}_{2}$, 2.6 Units of Taq polymerase, and nuclease-free water to a total volume of $50 \mu \mathrm{L}$. PCR cycle begins with a 2 -min incubation at $95^{\circ} \mathrm{C}$, then 25 cycles of $30 \mathrm{~s}$ at $94^{\circ} \mathrm{C}$, $30 \mathrm{~s}$ at $55^{\circ} \mathrm{C}, 45 \mathrm{~s}$ at $72^{\circ} \mathrm{C}$, followed by a $7-$ min incubation at $72^{\circ} \mathrm{C}$. The reaction can then be held at $4^{\circ} \mathrm{C}$.

6. PCR products are separated by electrophoresis on a $2 \%$ agarose gel and visualized by ethidium bromide staining.

7. For the $\mathrm{qPCR}$ reaction a $2-\mu \mathrm{L}$ aliquot of diluted cDNA template $(12.5 \mathrm{ng})$ is mixed with $10 \mu \mathrm{L}$ iQ SYBR Green Supermix (Bio-Rad), $150 \mathrm{nM}$ forward and reverse real-time PCR primers for $X b p 1$ or $G R P 78 / B i P G R P 78 / B i P$ or $\beta$-actin (internal control), and nuclease-free water to a final volume of $20 \mu \mathrm{L}$.

8. The thermal cycle parameters for $X b p 1$ or $G R P 78 / B i P$ are an initial step of $95^{\circ} \mathrm{C}$ for $10 \mathrm{~min}$, followed by $40-48$ cycles of $95^{\circ} \mathrm{C}$ for $15 \mathrm{~s}$ and $59^{\circ} \mathrm{C}$ for $1 \mathrm{~min}$; for the final step the reaction is terminated by holding at $4^{\circ} \mathrm{C}$.

9. The data are analyzed with the iCycler iQ real-time PCR detection system (Bio$\mathrm{Rad})$ according to the manufacturer's instructions.

\subsection{Nuclear DNA Fragmentation Assay}

During apoptosis, cells undergo many distinct morphological and biochemical changes. One striking event that occurs late in apoptosis involves endonuclease cleavage of DNA between nucleosomes, thereby producing a mixture or "ladder" of different sized DNA fragments. DNA fragmentation has been well recognized as a marker of the final stage of apoptosis (44). To detect ER stress-induced apoptosis in mammalian cultures:

1. Attached and floating cells are pooled by scraping and gently pelleted at $300-400 \times$ $g$ in a table-top swinging bucket centrifuge.

2. Cells are solubilized in DNA lysis buffer supplemented with $100 \mu \mathrm{g}$ of proteinase $\mathrm{K} / \mathrm{mL}$ to remove histone proteins, for $2 \mathrm{~h}$ at $50^{\circ} \mathrm{C}$.

3. DNA is extracted twice with phenol-chloroform mixed 1:1, and twice with chloroform alone.

4. DNA is precipitated by adding 0.8 volumes (w/r/t the aqueous phase from 3 ) of isopropanol and centrifuging at high speed for $15 \mathrm{~min}$.

5. The isopropanol/aqueous phase (containing the nucleic acid) is removed and the precipitated DNA is washed with $70 \%$ ethanol and allowed to dry briefly at room temperature.

6. The pellet is resuspended in $30-50 \mu \mathrm{L}$ of TE, $\mathrm{pH} 8$, supplemented with $0.25 \mathrm{mg} /$ $\mathrm{mL}$ RNAse A and $20-30 \mu \mathrm{g}$ of DNA ( $\mathrm{A}^{260}$ determined) is resolved on a $1.5 \%$ agarose gel (see Note 1).

\footnotetext{
${ }^{1} \mathrm{~A}$ laddered appearance of the DNA is indicative of apoptosis; a smeared appearance suggests the observed cell death is the result of some other form of cell death such as necrosis.
} 


\section{Acknowledgments}

Portions of this work were supported by NIH grants DK042394, HL052173, and HL057346. RJK is an Investigator of the Howard Hughes Medical Institute.

\section{References}

1. Kaufman RJ. Orchestrating the unfolded protein response in health and disease. J Clin Invest. 2002; 110:1389-1398. [PubMed: 12438434]

2. Mori K. Tripartite management of unfolded proteins in the endoplasmic reticulum. Cell. 2000; 101:451-454. [PubMed: 10850487]

3. Ron D, Walter P. Signal integration in the endoplasmic reticulum unfolded protein response. Nat Rev Mol Cell Biol. 2007; 8:519-529. [PubMed: 17565364]

4. Schroder M, Kaufman RJ. The Mammalian unfolded protein response. Annu Rev Biochem. 2005; 74:739-789. [PubMed: 15952902]

5. Harding HP, Zhang Y, Bertolotti A, Zeng H, Ron D. Perk is essential for translational regulation and cell survival during the unfolded protein response. Mol Cell. 2000; 5:897-904. [PubMed: 10882126]

6. Scheuner D, Song B, McEwen E, Liu C, Laybutt R, Gillespie P, et al. Translational control is required for the unfolded protein response and in vivo glucose homeostasis. Mol Cell. 2001; 7:1165-1176. [PubMed: 11430820]

7. Harding HP, Zhang Y, Zeng H, Novoa I, Lu PD, Calfon M, et al. An integrated stress response regulates amino acid metabolism and resistance to oxidative stress. Mol Cell. 2003; 11:619-633. [PubMed: 12667446]

8. Fribley AM, Evenchik B, Zeng Q, Park BK, Guan JY, Zhang H, et al. Proteasome inhibitor PS-341 induces apoptosis in cisplatin-resistant squamous cell carcinoma cells by induction of Noxa. J Biol Chem. 2006; 281:31440-31447. [PubMed: 16928686]

9. Ron D, Habener JF. CHOP, a novel developmentally regulated nuclear protein that dimerizes with transcription factors $\mathrm{C} / \mathrm{EBP}$ and LAP and functions as a dominant-negative inhibitor of gene transcription. Genes Dev. 1992; 6:439-453. [PubMed: 1547942]

10. Matsumoto M, Minami M, Takeda K, Sakao Y, Akira S. Ectopic expression of CHOP (GADD153). induces apoptosis in M1 myeloblastic leukemia cells. FEBS Lett. 1996; 395:143147. [PubMed: 8898082]

11. McCullough KD, Martindale JL, Klotz LO, Aw TY, Holbrook NJ. Gadd153 sensitizes cells to endoplasmic reticulum stress by down-regulating $\mathrm{Bcl} 2$ and perturbing the cellular redox state. Mol Cell Biol. 2001; 21:1249-1259. [PubMed: 11158311]

12. Ohoka N, Yoshii S, Hattori T, Onozaki K, Hayashi H. TRB3, a novel ER stress-inducible gene, is induced via ATF4-CHOP pathway and is involved in cell death. EMBO J. 2005; 24:1243-1255. [PubMed: 15775988]

13. Sok J, Wang XZ, Batchvarova N, Kuroda M, Harding H, Ron D. CHOP-Dependent stressinducible expression of a novel form of carbonic anhydrase VI. Mol Cell Biol. 1999; 19:495-504. [PubMed: 9858573]

14. Yamaguchi H, Wang HG. CHOP is involved in endoplasmic reticulum stress-induced apoptosis by enhancing DR5 expression in human carcinoma cells. J Biol Chem. 2004; 279:45495-45502. [PubMed: 15322075]

15. Zinszner H, Kuroda M, Wang X, Batchvarova N, Lightfoot RT, Remotti H, et al. CHOP is implicated in programmed cell death in response to impaired function of the endoplasmic reticulum. Genes Dev. 1998; 12:982-995. [PubMed: 9531536]

16. Marciniak SJ, Yun CY, Oyadomari S, Novoa I, Zhang Y, Jungreis R, et al. CHOP induces death by promoting protein synthesis and oxidation in the stressed endoplasmic reticulum. Genes Dev. 2004; 18:3066-3077. [PubMed: 15601821]

17. Wu J, Rutkowski DT, Dubois M, Swathirajan J, Saunders T, Wang J, et al. ATF6alpha optimizes long-term endoplasmic reticulum function to protect cells from chronic stress. Dev Cell. 2007; 13:351-364. [PubMed: 17765679] 
18. Tirasophon W, Welihinda AA, Kaufman RJ. A stress response pathway from the endoplasmic reticulum to the nucleus requires a novel bifunctional protein kinase/endoribonuclease (Ire1p). in mammalian cells. Genes Dev. 1998; 12:1812-1824. [PubMed: 9637683]

19. Wang XZ, Harding HP, Zhang Y, Jolicoeur EM, Kuroda M, Ron D. Cloning of mammalian Ire1 reveals diversity in the ER stress responses. EMBO J. 1998; 17:5708-5717. [PubMed: 9755171]

20. Calfon M, Zeng H, Urano F, Till JH, Hubbard SR, Harding HP, et al. IRE1 couples endoplasmic reticulum load to secretory capacity by processing the XBP-1 mRNA. Nature. 2002; 415:92-96. [PubMed: 11780124]

21. Lee AH, Iwakoshi NN, Glimcher LH. XBP-1 regulates a subset of endoplasmic reticulum resident chaperone genes in the unfolded protein response. Mol Cell Biol. 2003; 23:7448-7459. [PubMed: 14559994]

22. Shen X, Ellis RE, Lee K, Liu CY, Yang K, Solomon A, et al. Complementary signaling pathways regulate the unfolded protein response and are required for $C$. elegans development. Cell. 2001; 107:893-903. [PubMed: 11779465]

23. Yoshida H, Matsui T, Yamamoto A, Okada T, Mori K. XBP1 mRNA is induced by ATF6 and spliced by IRE1 in response to ER stress to produce a highly active transcription factor. Cell. 2001; 107:881-891. [PubMed: 11779464]

24. Urano F, Bertolotti A, Ron D. IRE1 and efferent signaling from the endoplasmic reticulum. J Cell Sci. 2000; 113:3697-3702. [PubMed: 11034898]

25. Yoneda T, Imaizumi K, Oono K, Yui D, Gomi F, Katayama T, et al. Activation of caspase-12, an endoplastic reticulum (ER). resident caspase, through tumor necrosis factor receptor-associated factor 2-dependent mechanism in response to the ER stress. J Biol Chem. 2001; 276:13935-13940. [PubMed: 11278723]

26. Nishitoh H, Saitoh M, Mochida Y, Takeda K, Nakano H, Rothe M, et al. ASK1 is essential for JNK/SAPK activation by TRAF2. Mol Cell. 1998; 2:389-395. [PubMed: 9774977]

27. Nishitoh H, Matsuzawa A, Tobiume K, Saegusa K, Takeda K, Inoue K, et al. ASK1 is essential for endoplasmic reticulum stress-induced neuronal cell death triggered by expanded polyglutamine repeats. Genes Dev. 2002; 16:1345-1355. [PubMed: 12050113]

28. Davis RJ. Signal transduction by the JNK group of MAP kinases. Cell. 2000; 103:239-252. [PubMed: 11057897]

29. Hetz C, Bernasconi P, Fisher J, Lee AH, Bassik MC, Antonsson B, et al. Proapoptotic BAX and BAK modulate the unfolded protein response by a direct interaction with IRE1alpha. Science. 2006; 312:572-576. [PubMed: 16645094]

30. Urano F, Wang X, Bertolotti A, Zhang Y, Chung P, Harding HP, et al. Coupling of stress in the ER to activation of JNK protein kinases by transmembrane protein kinase IRE1. Science. 2000; 287:664-666. [PubMed: 10650002]

31. Gunn KE, Gifford NM, Mori K, Brewer JW. A role for the unfolded protein response in optimizing antibody secretion. Mol Immunol. 2004; 41:919-927. [PubMed: 15261464]

32. Zong WX, Li C, Hatzivassiliou G, Lindsten T, Yu QC, Yuan J, et al. Bax and Bak can localize to the endoplasmic reticulum to initiate apoptosis. J Cell Biol. 2003; 162:59-69. [PubMed: 12847083]

33. Krajewski S, Tanaka S, Takayama S, Schibler MJ, Fenton W, Reed JC. Investigation of the subcellular distribution of the bcl-2 oncoprotein: residence in the nuclear envelope, endoplasmic reticulum, and outer mitochondrial membranes. Cancer Res. 1993; 53:4701-4714. [PubMed: 8402648]

34. Nakagawa T, Yuan J. Crosstalk between two cysteine protease families. Activation of caspase-12 by calpain in apoptosis. J Cell Biol. 2000; 150:887-894. [PubMed: 10953012]

35. Rao RV, Hermel E, Castro-Obregon S, del Rio G, Ellerby LM, Ellerby HM, et al. Coupling endoplasmic reticulum stress to the cell death program. Mechanism of caspase activation. J Biol Chem. 2001; 276:33869-33874. [PubMed: 11448953]

36. Tan Y, Dourdin N, Wu C, De Veyra T, Elce JS, Greer PA. Ubiquitous calpains promote caspase-12 and JNK activation during endoplasmic reticulum stress-induced apoptosis. J Biol Chem. 2006; 281:16016-16024. [PubMed: 16597616] 
37. Saleh M, Mathison JC, Wolinski MK, Bensinger SJ, Fitzgerald P, Droin N, et al. Enhanced bacterial clearance and sepsis resistance in caspase-12-deficient mice. Nature. 2006; 440:10641068. [PubMed: 16625199]

38. Fischer H, Koenig U, Eckhart L, Tschachler E. Human caspase 12 has acquired deleterious mutations. Biochem Biophys Res Commun. 2002; 293:722-726. [PubMed: 12054529]

39. Crompton M. The mitochondrial permeability transition pore and its role in cell death. Biochem J. 1999; 341(Pt 2):233-249. [PubMed: 10393078]

40. Feng B, Yao PM, Li Y, Devlin CM, Zhang D, Harding HP, et al. The endoplasmic reticulum is the site of cholesterol-induced cytotoxicity in macrophages. Nat Cell Biol. 2003; 5:781-792. [PubMed: 12907943]

41. Harding HP, Zeng H, Zhang Y, Jungries R, Chung P, Plesken H, et al. Diabetes mellitus and exocrine pancreatic dysfunction in perk-/- mice reveals a role for translational control in secretory cell survival. Mol Cell. 2001; 7:1153-1163. [PubMed: 11430819]

42. Zhou J, Lhotak S, Hilditch BA, Austin RC. Activation of the unfolded protein response occurs at all stages of atherosclerotic lesion development in apolipoprotein E-deficient mice. Circulation. 2005; 111:1814-1821. [PubMed: 15809369]

43. Fribley A, Zeng Q, Wang CY. Proteasome inhibitor PS-341 induces apoptosis through induction of endoplasmic reticulum stress-reactive oxygen species in head and neck squamous cell carcinoma cells. Mol Cell Biol. 2004; 24:9695-9704. [PubMed: 15509775]

44. Schwartzman RA, Cidlowski JA. Apoptosis: the biochemistry and molecular biology of programmed cell death. Endocr Rev. 1993; 14:133-151. [PubMed: 8325248] 


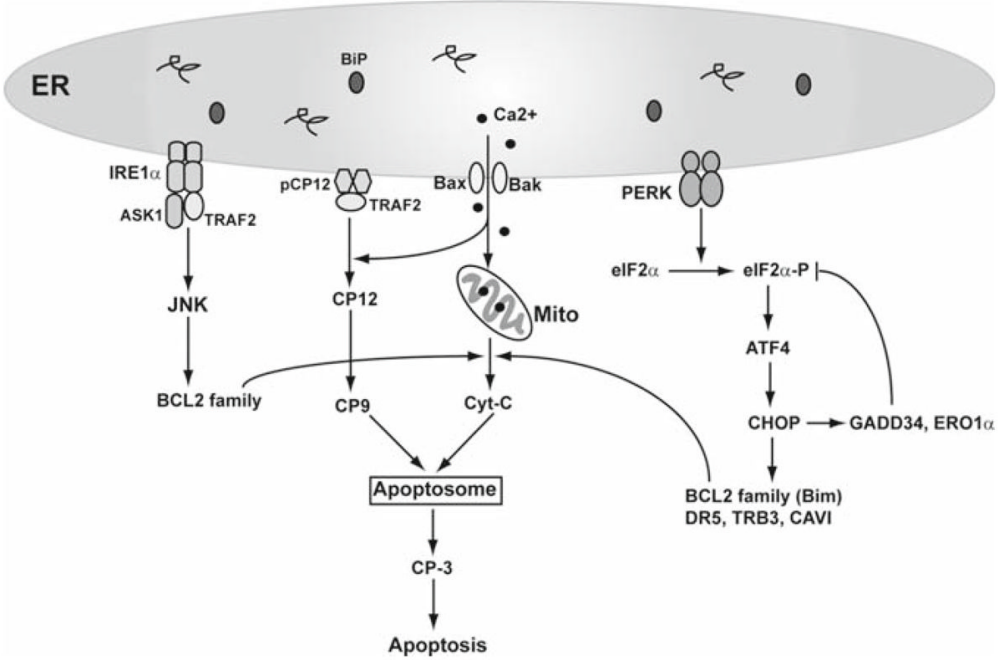

Fig. 1.

The apoptotic pathways regulated by the UPR. In response to ER stress, PERK, and IRE1a are activated through their homodimerization and autophosphorylation. Activated PERK phosphorylates translation initiation factor eIF2a, which can selectively induce expression of proapoptotic transcription factors ATF4 and CHOP. CHOP induces expression of numerous proapoptotic factors including DR5, TRB3, CAVI, and BCL2 family proteins. CHOP can also induce expression of GADD34 and ERO1a, leading to apoptosis by increasing protein synthesis and oxidation in the ER of stressed cells. On activation of the UPR, IRE1a serves as a scaffold protein to form a complex with TRAF2 and ASK1, which subsequently activates the JNK-mediated apoptotic pathway. Furthermore, ER stress can induce BAX and BAK localization and oligomerization at the ER, which promotes calcium release from the ER to the cytosol. Increased cytosolic calcium concentration stimulates calcium uptake into the mitochondrial matrix, which can result in depolarization of the inner membrane and transition of the outer membrane permeability pore. This causes cytochrome $c$ release and Apaf-1-dependent activation of the apoptosome leading to apoptosis. In addition, ER stress may also promote dissociation of TRAF2 from ER membrane-resident procaspase-12, allowing caspase-12 activation to mediate apoptosis. Mito Mitochondria, Cyt-c Cytochrome $c, p C P 12$ Procaspase-12, CP12 Caspase-12, CP9 Caspase-9, CP-3 Caspase-3. 